\title{
Study of Different Phosphorus Fractions and their Relationship with Soil Properties in Agricultural Botany Research Farm, Nagpur, India
}

\author{
Monika S. Bhavsar, Rajanikant B. Ghagare and Sugandh N. Shinde* \\ College of Agriculture, Nagpur, Maharashtra, India \\ *Corresponding author
}

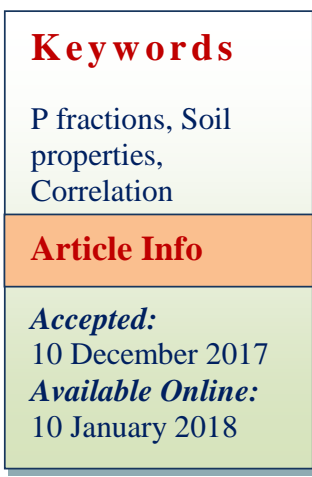

A B S T R A C T

Phosphorus fractionation study in soils of Agricultural Botany Research Farm, Nagpur were studied in relation to soil properties in which10 surface $(0-15 \mathrm{~cm}$ depth) and 10 subsurface $(15-30 \mathrm{~cm}$ depth) soil samples collected from studied area were analysed for different physical, chemical properties and different P fractions. Majority of the soils of the study area clayey in nature, neutral to moderately alkaline in reaction, Soil organic carbon was moderate to moderately high in soils, EC values for these soils within safe limit, the free lime content indicating that these soils are moderately calcareous in nature. The available phosphorus content of the soils showed low to moderately high in category. Occluded P had significant positive correlation with sand. Fe-P and Reduct-P had negative significant relation with silt and Ca-P had significant positive correlation. Saloid -P, Al-P, Reduct-P, Org-P and Total-P had significant positive correlation with clay. No one phosphorus form gave significant positive correlation with $\mathrm{pH}$ and E.C. Available $\mathrm{P}$ was significant positively correlated with Total-P, Organic-P, Ca-P. Organic carbon had significant positive correlation with Total-P, Organic-P, Fe-P, Ca-P. Clay was significant positively correlated with saloid-P, Al-P, Ca-P, Red-P, Organic-P, and Total-P. Silt was significant negatively correlated with Saloid-P, Fe-P, Red-P and positively correlated with Ca-P. Total P and Organic P had significant positive correlation with all the fractions except Occl-P was not showed significant relation with Total-P. All the forms of inorganic $\mathrm{P}$ were highly significant and positively correlated with each other except Al-P and OcclP.

\section{Introduction}

Phosphorus in soil present in organic and inorganic forms. Only 10 to 30 per cent of the freshly applied phosphate is utilized by crop plants and rest goes into the formation of different $\mathrm{P}$ compounds of varying solubility which later serve as potential source of $\mathrm{P}$ for plants (Kanwar, 1976).
The distribution of different forms of phosphorus and their relationship with each other as well as with different soil properties is useful to understand the capacity of soil to supply phosphorus to plants. Keeping in view the scanty information in this respect on soils of Agricultural Botany Research farm, Nagpur, the present investigation was undertaken. 


\section{Materials and Methods}

Ten surface $(0-15 \mathrm{~cm})$ and ten subsurface $(15-$ $30 \mathrm{~cm})$ soil samples collected from Agricultural Botany Research Farm, Nagpur were used for the study. The processed soil samples $(<2 \mathrm{~mm})$ were analyzed for $\mathrm{pH}, \mathrm{EC}$, Organic carbon, $\mathrm{CaCO}_{3}, \mathrm{CEC}, \mathrm{S}$ and, Silt, Clay and different $\mathrm{P}$ fractions by adopting standard procedures (Table 1 and 2). Total $\mathrm{P}$ in soil was determined using $60 \%$ perchloric acid digestion method as suggested by Piper (1966). The original fractionation procedure for different forms of inorganic $\mathrm{P}$ proposed by Peterson and Corey (1966) and available $\mathrm{P}$ by Olsen et al., (1954) were used. Organic P was determine as the difference between total $\mathrm{P}$ and Inorganic P. Simple correlation coefficient analyses between soil properties and fractions of $\mathrm{P}$ were computed by standard statistical methods.

\section{Results and Discussion}

\section{Inorganic-P}

\section{Saloid-P}

In Agricultural Botany Research Farms, Nagpur Saloid-P content of the soils decrease with depth and ranged from 2.1 to $3.7 \mathrm{ppm}$ and accounted on an average about 0.62 per cent of the total P. Sharma and Tripathi (1992) reported that, content of Saloid $\mathrm{P}$ on an average 0.8 percent of the total $\mathrm{P}$ and 1.6 per cent of the Inorganic $P$. The variation in Saloid $\mathrm{P}$ in the studied area soils can be attributed to the variation in clay, organic carbon and available P content of these soils. Saloid $\mathrm{P}$ had significant and positive with clay $\left(\mathrm{r}=0.638^{* *}\right)$. Similar result was reported in clayey soils of Rajasthan by Sacheti and Saxena (1973). Saloid P had significant and negative relationship with silt $\left(\mathrm{r}=-0.746^{* *}\right)$. It showed significant positive correlation with Org-P $\left(\mathrm{r}=0.519^{* *}\right)$, Total-P $\left(\mathrm{r}=0.568^{* *}\right)$, Red
-P $\left(\mathrm{r}=0.495^{*}\right)$, Fe-P $\left(\mathrm{r}=0.503^{* *}\right)$ and showed significant negative correlation with $\mathrm{Ca}-\mathrm{P}(\mathrm{r}=$ -0.512). The significant positive correlation of Saloid -P with Org-P and Total-P indicate that two forms have profound effect on the content and distribution of Saloid-P, Devra et al., (2014). The higher content of Saloid $-\mathrm{P}$ as a result of inorganic fertilization and FYM could be attributed to the transformation of applied P into Saloid-P. The result was agreement with Vishwanath and Doddamani (1991) and Jatav et al., (2010).

\section{Aluminium-P}

The distribution of Al-P decreased with sampling depth. This might be due to increase amount of calcium carbonate in the soil with increasing depth. The results corroborate the finding of Gupta and Cornfield (1962). The Al$\mathrm{P}$ varied from $40.56 \mathrm{ppm}$ to $53.15 \mathrm{ppm}$. It contributed about $10.12 \%$ of total-P. Al-P had significant and positive correlation with clay ( $\mathrm{r}$ $\left.=0.797^{* *}\right)$. It also showed significant negative correlation with $\mathrm{CaCO}_{3}(\mathrm{r}=-604 * *)$. Al-P had significant positive correlation with Org-P ( $\mathrm{r}$ $=0.506)$, Total-P $\left(\mathrm{r}=0.608^{* *}\right)$.

\section{Iron bound phosphorus (Fe-P)}

The Fe-P content shows variations in all samples. According to Table 3, Fe-P content varies between $14.15 \mathrm{ppm}$ to $28.34 \mathrm{ppm}$. It contributes 4.27 per cent of total P. These results were in accordance with that of Viswanath and Doddamani (1991). Fe-P was found higher in surface soil due to higher organic carbon content, higher amount of calcium carbonate was recorded at higher $\mathrm{pH}$ where iron activity was less to precipitate $\mathrm{P}$ into $\mathrm{Fe}$, Chandra Bhan and Harishankar (1973), Devra et al., (2014). The high organic carbon content increased the amount of Fe-P in studied area. Silt content showed significant and negative relationship with Fe-P $(\mathrm{r}=-$ $\left.0.646^{* *}\right)$. The Organic carbon had significant 
and positive relationship with $\mathrm{Fe}-\mathrm{P}(\mathrm{r}=$ $\left.0.502^{* *}\right)$. This might be due to the mineralization of organic $-\mathrm{P}$ and conversion into iron fraction due to high biological activity in the soils, Sacheti and Saxena (1973), Jaggi (1991). The high amount of free $\mathrm{CaCO}_{3}$ was found at high $\mathrm{pH}$ at which $\mathrm{Fe}-\mathrm{P}$ activity was less to precipitate $\mathrm{P}$ into Fe-P. Similar finding were also reported by Chander Bhan and Harishankar (1973) and Viswanath and Doddamani (1991).

Fe-P showed significant and positive with Saloid-P ( $\left.\mathrm{r}=0.503^{* *}\right)$, Red-P $\left(\mathrm{r}=0.725^{* *}\right)$, Org-P ( $\left.\mathrm{r}=0.448^{*}\right)$, Total-P $\left(\mathrm{r}=0.507^{* *}\right)$. Similar result was found by Devra (2014).

\section{Calcium-P}

Ca- $\mathrm{P}$ was found to be most dominant amongst all the forms of phosphorus. The $\mathrm{Ca}-\mathrm{P}$ varied from $182.09 \mathrm{ppm}$ to $208.45 \mathrm{ppm}$ and accounted about 41.11 per cent of total $P$. This might be attributed with finding of Mishra and Ojha (1969) and Viswanath and Doddamani (1991). Ca-p was increased with increasing depth similar result was obtained by Trivedi (2010). Available P showed significant and positively correlated with $\mathrm{Ca}-\mathrm{P}(\mathrm{r}=0.652 * *)$. Similar finding is reported by Lungamuana et al., (2012). Being constant with correlation analysis $\mathrm{Ca}-\mathrm{P}$ had low direct and indirect path coefficient.

The transformation mainly occurred among other $\mathrm{Pi}$ fraction. $\mathrm{P}$ added to the soil was distributed between labiale and non-labiale pools. Shen et al., (2004) found that, labile P (Ca-P, Al-P) could be readily fixed into nonlabiale $\mathrm{P}$ (Fe-P, Occl-P and $\mathrm{Ca}-\mathrm{P}$ ) due to the associated with hydrous $\mathrm{Fe}$ oxides and calcareous compound in calcareous soil result reported by Wang (2010) significant relationship of $\mathrm{Ca}-\mathrm{P}$ with available $\mathrm{P}$ indicating that these fraction mainly contributed towards available $\mathrm{P}$ pool. $\mathrm{Ca}-\mathrm{P}$ had showed significant positive correlation with silt $\left(\mathrm{r}=0.583^{* *}\right)$, OC $\left(\mathrm{r}=0.499^{*}\right)$, $\mathrm{CaCO}_{3}\left(\mathrm{r}=0.508^{* *}\right)$, available $\mathrm{P}\left(0.652^{* *}\right)$.

Ca-P showed significant negative correlation with Saloid-P ( $\left.\mathrm{r}=-0.512^{* *}\right)$ and Fe-P $(\mathrm{r}=-$ $0.683)$, Red-P ( $\left.\mathrm{r}=-0.548^{* *}\right)$ and showed significant positive correlation with Occl-P ( $\mathrm{r}$ $=0.510 * *)$, Org-P $(\mathrm{r}=0.573 * *)$, Total-P $(\mathrm{r}$ $\left.=0.498^{*}\right)$. The close association of Ca-P with Total-P was due to the dominance of $\mathrm{Ca}-\mathrm{P}$ in soils. Similar results were also reported by Patgiri and Dutta (1993).

\section{Reductant-P}

The Reductant $-\mathrm{P}$ varied from $23.99 \mathrm{ppm}$ to $39.13 \mathrm{ppm}$. It accounted about 6.88 per cent of the total-P. The low value of Red $-\mathrm{P}$ was observed in the soil having relatively higher $\mathrm{pH}$ and sand content. This might be due to iron and aluminum bound $\mathrm{P}$ content and rise in the content of calcium bound $\mathrm{P}$ and also Red$\mathrm{P}$. Red-P had negative significant correlation with $\mathrm{pH}(\mathrm{r}=-0.642 * *)$, silt $(\mathrm{r}=-0.520 * *)$.

It showed significant positive correlation with clay $\left(r=0.494^{*}\right)$. Similar finding were observed by Viswanath and Doddamani (1991), Sharma and Tripathi (1992), Trivedi et al., (2010).

Red-P had significant positive correlation with Saloid-P $\left(\mathrm{r}=0.495^{*}\right), \mathrm{Fe}-\mathrm{P}\left(\mathrm{r}=0.725^{* *}\right)$, Org-P $\left(\mathrm{r}=493^{*}\right)$, Total-P $\left(\mathrm{r}=0.606^{* *}\right)$ and showed significant negative correlation with Ca-P ( $\left.\mathrm{r}=-0.548^{* *}\right)$.Prasad et al., (1986) showed that all the forms of $\mathrm{P}$ are correlated with each other.

\section{Occluded-P}

The Occluded $-\mathrm{P}$ ranged from $14.88 \mathrm{ppm}$ to $25.30 \mathrm{ppm}$. It accounted about 4.53 per cent of total-P. Similar the results were found by Singh and Omankar (1987). 
Table.1 Physical properties of soils in Agricultural Botany Research Farm, Nagpur

\begin{tabular}{|c|c|c|c|c|c|}
\hline \multirow{2}{*}{ Sr. no } & Depth (cm) & \multicolumn{2}{|c|}{ Particle size distribution (per cent) } & $\begin{array}{c}\text { Textural } \\
\text { class }\end{array}$ \\
\hline & & Sand \% & Silt \% & Clay \% & Clayey \\
\hline BOT-1(1) & $0-15$ & 18.5 & 19.8 & 56.90 & Clayey \\
\hline BOT-1(2) & $15-30$ & 20.5 & 20.86 & 53.75 & Clayey \\
\hline BOT-1(3) & $0-15$ & 19.53 & 24.20 & 56.27 & Clayey \\
\hline BOT-1(4) & $15-30$ & 21.37 & 25.33 & 52.20 & Clayey \\
\hline BOT-2(5) & $0-15$ & 16.5 & 22.10 & 58.56 & Clayey \\
\hline BOT-2(6) & $15-30$ & 18.1 & 23.70 & 55.00 & Clayey \\
\hline BOT-2(7) & $0-15$ & 19.50 & 23.50 & 56.32 & Clayey \\
\hline BOT-2(8) & $15-30$ & 21.80 & 21.20 & 53.20 & Clayey \\
\hline BOT-3(9) & $0-15$ & 20.22 & 21.53 & 58.25 & Clayey \\
\hline BOT-3(10) & $15-30$ & 21.1 & 20.5 & 55.03 & Clayey \\
\hline BOT-3(11) & $0-15$ & 17.20 & 21.6 & 58.88 & Clayey \\
\hline BOT-3(12) & $15-30$ & 19.60 & 22.3 & 56.20 & Clayey \\
\hline BOT-4(13) & $0-15$ & 18.81 & 22.40 & 58.80 & Clayey \\
\hline BOT-4(14) & $15-30$ & 20.95 & 20.55 & 56.3 & Clayey \\
\hline BOT-4(15) & $0-15$ & 20.70 & 22.50 & 56.71 & Clayey \\
\hline BOT-4(16) & $15-30$ & 21.30 & 25.20 & 52.60 & Clayey \\
\hline BOT-5(17) & $0-15$ & 18.96 & 21.07 & 58.24 & Clayey \\
\hline BOT-5(18) & $15-30$ & 19.51 & 22.46 & 55.09 & Clayey \\
\hline BOT-5(19) & $0-15$ & 20.87 & 22.75 & 55.30 & Clayey \\
\hline BOT-5(20) & $0-15$ & 22.59 & 24.17 & 53.24 & \\
\hline
\end{tabular}

Table.2 Chemical properties of soils in Agricultural Botany Farm, Nagpur

\begin{tabular}{|l|c|c|c|c|c|c|}
\hline Sr. no & $\begin{array}{c}\text { Depth } \\
(\mathbf{c m})\end{array}$ & $\begin{array}{c}\mathbf{p H} \\
(\mathbf{1 : 2 . 5})\end{array}$ & $\begin{array}{c}\mathbf{E C} \\
\mathbf{d S m}\end{array}$ & $\begin{array}{c}\text { Organic } \\
\text { Carbon }(\%)\end{array}$ & $\begin{array}{c}\mathbf{C a C O}_{3} \\
(\%)\end{array}$ & $\begin{array}{c}\text { Available Phosphorus } \\
\left(\mathbf{k g ~ h a ~}^{-1}\right)\end{array}$ \\
\hline BOT-1(1) & $0-15$ & 7.3 & 0.24 & 0.71 & 4.52 & 15.21 \\
\hline BOT-1(2) & $15-30$ & 7.5 & 0.25 & 0.67 & 4.91 & 12.30 \\
\hline BOT-1(3) & $0-15$ & 7.6 & 0.31 & 0.79 & 4.70 & 16.25 \\
\hline BOT-1(4) & $15-30$ & 7.9 & 0.38 & 0.71 & 5.12 & 14.01 \\
\hline BOT-2(5) & $0-15$ & 7.7 & 0.40 & 0.58 & 3.68 & 16.60 \\
\hline BOT-2(6) & $15-30$ & 7.9 & 0.42 & 0.52 & 4.75 & 18.17 \\
\hline BOT-2(7) & $0-15$ & 7.4 & 0.26 & 0.65 & 4.50 & 15.10 \\
\hline BOT-2(8) & $15-30$ & 7.8 & 0.31 & 0.60 & 5.61 & 14.11 \\
\hline BOT-3(9) & $0-15$ & 7.8 & 0.33 & 0.73 & 4.56 & 12.15 \\
\hline BOT-3(10) & $15-30$ & 8.0 & 0.39 & 0.68 & 5.14 & 17.20 \\
\hline BOT-3(11) & $0-15$ & 7.5 & 0.36 & 0.68 & 4.96 & 13.18 \\
\hline BOT-3(12) & $15-30$ & 8.0 & 0.38 & 0.61 & 5.39 & 11.23 \\
\hline BOT-4(13) & $0-15$ & 7.7 & 0.35 & 0.78 & 4.61 & 16.33 \\
\hline BOT-4(14) & $15-30$ & 8.1 & 0.40 & 0.72 & 5.25 & 14.18 \\
\hline BOT-4(15) & $0-15$ & 7.4 & 0.30 & 0.54 & 4.57 & 17.21 \\
\hline BOT-4(16) & $15-30$ & 7.6 & 0.34 & 0.47 & 5.48 & 15.36 \\
\hline BOT-5(17) & $0-15$ & 7.7 & 0.35 & 0.68 & 3.87 & 18.30 \\
\hline BOT-5(18) & $15-30$ & 7.8 & 0.37 & 0.62 & 4.76 & 16.19 \\
\hline BOT-5(19) & $0-15$ & 7.4 & 0.36 & 0.65 & 4.45 & \\
\hline BOT-5(20) & $15-30$ & 7.6 & 0.39 & 0.58 & 4.80 & \\
\hline
\end{tabular}


Table.3 Distribution of soil phosphorus form (ppm) in Agricultural Botany Research Farm, Nagpur

\begin{tabular}{|c|c|c|c|c|c|c|c|c|c|c|}
\hline Sr.no & $\begin{array}{c}\text { Depth } \\
\text { cm }\end{array}$ & S- P & Al- $\mathbf{P}$ & Fe- $P$ & Ca-P & $\begin{array}{c}\text { Red- } \\
\text { P }\end{array}$ & $\begin{array}{c}\text { Occl- } \\
\mathbf{P}\end{array}$ & $\begin{array}{c}\text { Inorg- } \\
\text { p }\end{array}$ & Org-P & $\begin{array}{c}\text { Total- } \\
\mathbf{P}\end{array}$ \\
\hline BOT-1(1) & $0-15$ & 3.7 & 8.38 & 28.34 & & 39.13 & 18.34 & 319.98 & 170.6 & 490.58 \\
\hline & & 2.8 & & & & & & & & \\
\hline BOT-1(3) & -15 & 2.6 & 47.12 & 19.34 & 194.34 & 32.67 & 14.88 & 310.95 & 184.25 & 95.20 \\
\hline BOT-1(4) & $15-30$ & 2.1 & 42.15 & 15.75 & 203.48 & 27.45 & 17.13 & 308.06 & 132.3 & 440.36 \\
\hline BOT- & $0-15$ & 3.4 & 50.14 & 15.70 & 196.14 & 30.15 & 15.98 & .J1 & 159.28 & 480.79 \\
\hline BOT-2(6) & $15-30$ & 2.5 & 42.24 & 14.53 & 201.41 & 23.99 & 19.12 & & 89.34 & 393.16 \\
\hline BOT-2(7) & $0-15$ & 3.0 & 47.20 & 20.12 & & 33.56 & 21.45 & & 174.02 & 498.23 \\
\hline BOT-2(8) & $15-30$ & 2.9 & 40.56 & 16.32 & 202.47 & 28.70 & 25.23 & .18 & 140.49 & 456.67 \\
\hline BOT- & & 3.1 & 48.84 & 24.36 & 193.2 & 31.45 & 18.45 & & 162.87 & 482.27 \\
\hline & & 3.5 & & & & 26.75 & & & & \\
\hline BOT. & $0-15$ & 3.6 & 50.55 & 23.70 & 199.34 & 39.10 & 22.2 & 338.59 & 173.44 & 512.03 \\
\hline BOT-3 & $15-30$ & 2.8 & 43.12 & 19.34 & 207 & 35.10 & 20.34 & 68 & 127 & 456.45 \\
\hline BOT- & & 3.2 & & & & & & & & 491.73 \\
\hline & & 3.0 & 48.14 & 15.70 & 206.44 & 30.17 & 21.66 & & 128 & 454.02 \\
\hline BOT-4(15) & $0-15$ & 2.5 & 53.15 & 20.18 & 201.25 & 30.45 & 22.45 & 329.98 & 143.55 & 473.53 \\
\hline BOT-4(16) & $15-30$ & 2.2 & 46.67 & & & 26.47 & 25.3 & & & 412.46 \\
\hline BOT-5(17) & & 3.0 & 52.14 & 22.18 & 195.89 & 35.18 & 21.52 & 328.91 & 129.37 & 458.28 \\
\hline BOT-5(18) & & 2.7 & & & & 32.12 & 23.5 & 323.68 & 96.68 & 420.36 \\
\hline BOT-5(19) & & 2.8 & 47.12 & 24.36 & 201.45 & 33.06 & 20.86 & 327.15 & 140.29 & 467.44 \\
\hline BOT-5(20) & $15-30$ & 2.3 & 42.56 & 21.12 & 207.13 & 29.45 & 24.35 & 327.41 & 83.21 & 410.62 \\
\hline
\end{tabular}

Table.4 Correlation coefficient(r) between forms of phosphorus with physic - Chemical properties of soils in Agricultural Botany Research Farm, Nagpur

\begin{tabular}{|c|c|c|c|c|c|c|c|c|}
\hline $\begin{array}{c}\text { Form of } \\
\qquad P\end{array}$ & Sand \% & Silt \% & Clay \% & pH & $\begin{array}{c}\text { EC } \\
\mathrm{dSm}^{-1}\end{array}$ & O.C\% & $\begin{array}{c}\mathrm{CaCO}_{3} \\
\%\end{array}$ & $\begin{array}{l}\text { A vailable } \\
\text { P kg }^{-1} \mathrm{ha}\end{array}$ \\
\hline Saloid-P & -0.266 & $-0.746^{* *}$ & $0.638 * *$ & -0.011 & 0.188 & 0.363 & -0.254 & 0.017 \\
\hline Al- P & -0.342 & -0.173 & $0.797 * *$ & -0.081 & 0.064 & 0.198 & $-0.604 * *$ & 0.249 \\
\hline $\mathrm{Fe}-\mathrm{P}$ & -0.006 & $-0.646^{* *}$ & 0.378 & -0.353 & -0.254 & $0.502 * *$ & -0.330 & 0.247 \\
\hline $\mathbf{C a}-\mathbf{P}$ & 0.363 & $0.583^{* *}$ & -0.443 & 0.162 & 0.474 & $0.499 *$ & $0.508 * *$ & $0.652 * *$ \\
\hline Red-P & -0.319 & $-0.520 * *$ & $0.494 *$ & $-0.642 * *$ & -0.292 & 0.445 & -0.272 & 0.244 \\
\hline Occl- P & $0.605^{* *} *$ & -0.044 & -0.433 & -0.011 & 0.303 & $-0.542 * *$ & $0.469 *$ & -0.128 \\
\hline Inorg.-P & 0.160 & -0.266 & 0.335 & -0.402 & 0.234 & 0.012 & -0.036 & 0.241 \\
\hline Org.- P & -0.354 & -0.327 & $0.638 * *$ & -0.170 & -0.417 & $0.651 * *$ & -0.305 & $0.454^{*}$ \\
\hline Total- P & -0.322 & -0.378 & $0.706^{* *}$ & -0.261 & -0.311 & $0.597 * *$ & -0.330 & $0.501 * *$ \\
\hline
\end{tabular}

** Significant at 1 per cent level

* Significant at 5 per cent level 
Table.5 Correlation coefficient (r) amongst the forms of phosphorus

\begin{tabular}{|c|c|c|c|c|c|c|c|c|}
\hline Forms of $\mathbf{P}$ & S-P & Al-P & Fe-P & Ca-P & R-S-P & Occl-P & Org-P & Total-P \\
\hline S-P & 1 & & & & & & & \\
\hline Al-P & 0.317 & 1 & & & & & & \\
\hline Fe-P & $0.503 * *$ & 0.203 & 1 & & & & & \\
\hline Ca-P & $-0.512 * *$ & -0.279 & $-0.683 * *$ & 1 & & & & \\
\hline R-S-P & $0.495^{*}$ & 0.371 & $0.725^{* *}$ & $-0.548 * *$ & 1 & & & \\
\hline Occl-P & 0.122 & 0.210 & 0.164 & $0.510 * *$ & -0.111 & 1 & & \\
\hline Org-P & 0.519 ** & $0.506^{* *}$ & $0.448^{*}$ & $0.573^{* *}$ & $0.493 *$ & $0.550^{* *}$ & 1 & \\
\hline Total-P & $0.568^{* * *}$ & $0.608^{* *}$ & $0.507 * *$ & $0.498 *$ & $0.606^{* *}$ & -0.411 & $0.968 * *$ & 1 \\
\hline
\end{tabular}

Occl-P had significant and positive correlation with sand $\left(\mathrm{r}=0.605^{* *}\right), \mathrm{CaCO}_{3}(\mathrm{r}$ $\left.=469^{*}\right)$ and negatively correlated with organic carbon $\left(\mathrm{r}=-0.542^{* *}\right)$. It showed significant positive correlation with $\mathrm{Ca}-\mathrm{P}\left(\mathrm{r}=510^{* *}\right)$ and $\operatorname{Org}-\mathrm{P}\left(\mathrm{r}=0.550^{* *}\right)$.

\section{Organic-P}

The organic $\mathrm{P}$ was mainly located in fulvic acid fractions. The soils having high organic matter content generally have high Organic P. Org-P content in the soils decreased with depth. The Org-P content in the soil varied from $83.21 \mathrm{ppm}$ to $184.25 \mathrm{ppm}$ which contributed about 28.58 per cent of the totalP. Khan and Mandal (1973) reported that, the Org-P constituted 29.82 per cent of the total P. Similar trend was also reported by Kothandarman and Krishnamoorthy (1978). In generally Org-P and its per cent to total P was found to decrease with depth. The decrease of organic phosphorus in soil may be attributed to the decreased of organic matter and organic carbon with depth. Similar trends were recorded by the Kothandaraman and Krishnammorthy (1977), Viswanath and Doddamani (1991). Since all soils were calcareous in nature, organic phosphorus was relatively low.

Org -P had significant positive relationship with $\mathrm{OC}\left(\mathrm{r}=651^{* *}\right)$. It appears that several phosphorus containing organic compounds dominate the soils and on mineralization will be available to crops. Similar observation was recorded by Kothandaraman and Krishanmoorthy (1977) and Viswanath and Doddamani (1991).

Organic $\mathrm{P}$ showed significant and positive correlation with available $\mathrm{P}(\mathrm{r}=0.454 *)$. Availability and forms $\mathrm{P}$ in the soil to a large extent are influenced by organic matter application. Some investigations carried out on decomposition of plant and animal residues, revealed that in initial stage of humification, large part of inorganic $\mathrm{P}$ gets converted into organic compound but later on when the sources of available energy is exhausted, mineralization of Org-P compound was detected. The increase in the availability $\mathrm{P}$ was due to mineralization of Org-P solublization of negative inorganic $\mathrm{P}$ and lesser fixation of added $\mathrm{P}$ Tomar et al., (1984). Org-P showed significant and positive relationship with clay $\left(\mathrm{r}=0.638^{* *}\right)$. However, organic phosphorus was significantly and positively correlated with Saloid P $\left(0.519^{* *}\right)$, Al-P $\left(\mathrm{r}=0.506^{* *}\right)$, Fe $\left(\mathrm{r}=0.448^{* *}\right), \quad$ Ca-P $\quad\left(\mathrm{r}=0.573^{* *}\right), \quad$ Red-P $\left(\mathrm{r}=493^{*}\right)$. Occl-P $\left(\mathrm{r}=0.550^{* *}\right)$, Total-P $(\mathrm{r}$ $\left.=0.968^{* *}\right)$. The association between Organic$\mathrm{P}$ and total-P which was evident because of higher correlation value of Organic and TotalP, had been reported by Dongale (1993) 


\section{Total-P}

The Total P content indicates the reserves of this element in the soil. The total $\mathrm{P}$ content in the soils of Agricultural Botany Research Farm, Nagpur varied from $393.16 \mathrm{ppm}$ to $512.03 \mathrm{ppm}$. The range was quite large which might be due to variation in crop management practices. The total $\mathrm{P}$ content in the soils was generally higher in the surface layer than in subsurface layer and decreased with depth. The decreased in total-P content may be due to decrease in organic matter content down to depth of soil. Similar result, also reported by Viswanath and Doddamani (1991) and Dongale (1993). Total-P had significant and positive correlation with clay $\left(\mathrm{r}=0.706^{* *}\right)$, organic carbon $\left(\mathrm{r}=0.597^{* *}\right)$, available $\mathrm{P}(\mathrm{r}=$ $\left.0.501^{* *}\right)$. Similar results were also reported by Gupta and Lattoo (1999) and Trivedi et al., (2010), Agrawal (1987) and Singh et al., (2010) (Table 4 and 5).

Total $\mathrm{P}$ was significantly and positively correlated with Saloid P $\left(\mathrm{r}=0.568^{* *}\right)$, Al-P ( $\mathrm{r}$ $\left.=0.608^{* *}\right), \quad \mathrm{Fe}-\mathrm{P} \quad\left(\mathrm{r}=0.507^{* *}\right), \quad$ Ca-P $\quad(\mathrm{r}$ $\left.=0.498^{*}\right), \quad$ Red-P $\quad\left(\mathrm{r} \quad=0.606^{* *}\right), \quad$ Org- $\mathrm{P}$ $\left(0.968^{* *}\right)$. The Ca-P was the predominate form of soil phosphorus, and was significantly and positively correlated with total $\mathrm{P}$ because of the close association of $\mathrm{Ca}-\mathrm{P}$ with total-P due to the dominance of Ca-P in soils. Similar results were also reported by Patgiri and Dutta (1993).

\section{References}

Agarwal,. S, T. A. Singh, and V. Bhardwaj, 1987. Inorganic soil phosphorus fraction and available phosphorus fractions as affected by long term fertilization and cropping pattern in Ninital Tarai, J. Indian Soc. Soil Sci. 35:25-28

Bhan and Harishankar, 1973. Study on forms and contents of soil phosphorus and their interrelationship with some physico-chemical characteristics of selected soils of Uttar Pradesh. J. Indian Soci. Soil Sci. 21, 177-180.

Devra, P., S. R. Yadav and I. J. Gulati, 2014. Distribution of different phosphorus fractions and their relationship with soil properties in western plain of Rajasthan. Agropedology, 24 (1):20-28.

Dongale, J. H., 1993. Depthwise distribution of different forms of phosphorus in lateritic soils of coastal region. J. Indian Soc. Soil Sci, 41(1):62-66.

Gupta, J. P. and A. K. Lattoo, 1999. Distribution of different forms of phosphorus in the soils of subtropical zone of Jammu Region J. Indian Soci. Soil Sci. 47, 147-148.

Gupta, M. B. S. and A. H. Cornfield, 1962. Dynamics of phosphorus. Leading paper presented by N. K. Tomar at $65^{\text {th }}$ annual convention of Indian Society of Soil Science seminar, at NBSS and LUP Nagpur.

Jaggi, R. C., 1991. Inorganic phosphate fractions as related to soil properties in some Representative soils of Himachal Pradesh. J. Indian Soc. Soil Sci. 39: 567-568.

Jatav, M. K., K. C. Sud and S. P. Trehan, 2010. Effect of organic and inorganic sources of phosphorus and potassium on their different fractions under potatoRadish Cropping Sequence in a brown hill soil, Journal of the Indian society of Soil science, Vol. 58, No. 4, pp 388393.

Kanwar, J. S. 1976. Soil fertility theory and practice (Indian Council of Agricultural Research, New Delhi).

Khan and Mandal, 1973.The distribution of different inorganic forms of phosphorus in rice soils of West Bengal. J. Indian Soc. Soil Sci. 21(4): 395-402.

Kothandaraman, G. V. and K. K. Krishanamoorthy, 1977. Distribution of 
inorganic phosphorus fractions in Tamil Nadu soil. Madras Agricultural J.64:516-521. Shrivastava, O. P. and A. N. Pathak, 1970. Effect of texture on the availability of soil phosphorus. Phosphorsaure. 28:181-187.

Lungmuana, S. K. Ghosh and P. K. Patra, 2012. Distribution of different forms of phosphorus in surface soil of rice Areas of red and latererite zone of West Bengal. J. Indian Soc. Soil Sci. vol 60(3): 204-207.

Mishra, M. L. and S. K. Ojha, 1969. Release of retained phosphorus by various extractants. J. Indian Soc Soil Sci. 17(1): 67-74.

Olsen, S. R., Cole, C. V., Watanabe, F.S. and Dean, L.A. 1954. Estimation of available phosphorus in soils by extraction with sodium bicarbonate U.S. D.A circular 939.

Patgiri, D.K and Dutta, K. 1993. Forms and distribution of phosphorus in some tea growing soils. Journal of the Indian Society of Soil Science, 41, 346-348.

Peterson, G.W. and R.B. Corey, 1966. Modified Chang and Jackson procedure for routine fractionation of Inorganic soil phosphate. Pro. Soil Sci. Amer. 30: 563.

Piper, C.S. 1966. Soil and plant analysis iv edition. University of Acelcide Adeitada, Australia. Pp. 135-200.

Prasad, S. N., Singh, S. N., and Singh, R.C. 1966. Correlation studied between forms of $\mathrm{P}$ and soil properties. Journal of Applied Biology, 4, 55-58.

Sacheti, A. K. and S. N. Saxena, 1973.
Relationship between some soil characteristics and various inorganic phosphate fractions of soils of Rajasthan J. Indian Soc. Soil Sci. 21: 143-149.

Sharma, P. K. and B.R. Tripathi, 1992. Fractions of phosphorus from some acid hill soils of North-West India. J. Indian. Soc. Soil. Sci. Vol. 40: 59-65.

Shen, J., R., Zhang, F., Fan, J., Tang and Z. Rengel, 2004. Crop yields, soil fertility and phosphorus fractions in response to long term fertilization under the rice monoculture system on a calcareous soil. Field crop Res. 86: 225- 238.

Singh, R and P. K. Omankar, 1987. Phosphorus forms in some soil of midwestern Uttar Pradesh. Profile distribution and transformation of phosphorus. J. Indian Soc. Soil Sci., 35(4): 634-641

Trivedi S. K., R. A. S. Tomar, P. S. Tomar and Naresh Gupta. 2010. Vertical distribution of different forms of phosphorus in Alluvial soils of Gird Region of Madhya Pradesh. J. Indian Soc. Soil sci. Vol. 58(1): 86-90.

Vishwanath, J. and V. S. Doddamani 1991. Distribution of $\mathrm{P}$ fractions in some Vertisols. J. Indian Soc. Soil Sci. 39: $441-445$.

Wang, J., W. Z. Liu, H. F. Mu and T. H. Dang.2010. Inorganic phosphorus fractions and phosphorus availability in a calcareous soil receiving 21-year superphosphate application.

Pedosphere. 20(3): 304-310.

\section{How to cite this article:}

Monika S. Bhavsar, Rajanikant B. Ghagare and Sugandh N. Shinde. 2018. Study of Different Phosphorus Fractions and their Relationship with Soil Properties in Agricultural Botany Research Farm, Nagpur, India. Int.J.Curr.Microbiol.App.Sci. 7(01): 1130-1137. doi: https://doi.org/10.20546/ijcmas.2018.701.137 